\title{
REVIEW
}

\section{Male sex determination: insights into molecular mechanisms}

\author{
Kathryn McClelland, Josephine Bowles and Peter Koopman
}

Disorders of sex development often arise from anomalies in the molecular or cellular networks that guide the differentiation of the embryonic gonad into either a testis or an ovary, two functionally distinct organs. The activation of the Y-linked gene Sry (sexdetermining region $\eta$ and its downstream target Sox9 (Sry box-containing gene 9) triggers testis differentiation by stimulating the differentiation of Sertoli cells, which then direct testis morphogenesis. Once engaged, a genetic pathway promotes the testis development while actively suppressing genes involved in ovarian development. This review focuses on the events of testis determination and the struggle to maintain male fate in the face of antagonistic pressure from the underlying female programme. Asian Journal of Andrology (2012) 14, 164-171; doi:10.1038/aja.2011.169; published online 19 December 2011

Keywords: gonadal; knockout; mice; sex determination; sex-determining region Y protein; sex disorders; sex reversal; sexual development; testis

\section{INTRODUCTION}

Perceptions of sex and sexuality pervade modern culture. However, it is important to recognize that not all members of our society fit comfortably the socially constructed ideas of masculinity and femininity. These people are likely to struggle with a variety of medical and psychosocial issues surrounding their sexuality. ${ }^{1,2}$ It is estimated that $1.7 \%$ of all live births have a disorder of sex development (DSD)., These conditions are congenital and are characterized by chromosomal or gonadal sex that does not match outward appearance of maleness or femaleness, or anatomical sex that is in some way ambiguous or intermediate between male and female. ${ }^{4}$ Some of these conditions are associated with infertility, predisposition to gonadal tumours and/or other syndromic features. ${ }^{5,6}$ Clearly, discovery of the underlying molecular causes of DSDs is an important goal in biomedical research.

Genomic and structure/function studies of human DSDs have revealed a number of genes as being important for sex development, while studies in the mouse have further extended our understanding of the mechanism of action of these genes; these approaches are complementary. Identifying the molecular mechanisms behind sex determination and differentiation will lead to more accurate diagnosis and prognosis, and assist in providing more informed options for psychological, endocrinological, surgical and other clinical management of DSDs, many of which remain uncharacterized at a molecular level. In a broader context, understanding the events of early testis development may also illuminate some of the underlying causes of male infertility.

In this review, we examine the molecular mechanisms behind male sex determination and differentiation, and how impairment of these mechanisms underlies a subset of human DSDs. In particular, we highlight the interplay between the molecular pathways that promote male and female development, and the role of gene dosage and phenotype sensitivity in mice and humans.

\section{SRY AND THE BEGINNINGS OF MALENESS}

We each inherit an X or a Y sex chromosome from our father and an X chromosome from our mother during fertilisation. The resulting chromosomal sex (XX or XY) leads to the transformation of the embryo into a male or a female. Before gonadal sex determination in both XX and XY embryos, a bipotential gonadal primordium exists that has the potential to differentiate into either testes or ovaries. Activation of the Y-linked gene Sry (sex-determining region $Y$ ) initiates testicular development. When Sry is expressed ectopically in XX mice, the testis pathway is initiated. ${ }^{7}$ When Sry is not present, as in XX individuals, or non-functional in XY individuals, the bipotential gonads generally do not follow the testicular pathway and instead develop into ovaries. ${ }^{8,9}$

SRY plays a role in a number of DSDs: mutation or loss of function of SRY results in complete male to female sex reversal, ${ }^{10,11}$ whereas ectopic expression of SRY in XX individuals due to chromosomal translocation of SRY may result in female to male sex reversal. Indeed, SRY translocation is responsible for $10 \%$ of all $46, \mathrm{XX}$ female to male sex reversal. ${ }^{12}$ Formation of ovotestes, where ovarian and testicular tissues coexist in the same organ, can also occur in cases of ectopic SRY activity. ${ }^{13,14}$

SRY is a transcription factor with a DNA-binding high-mobility group box domain. ${ }^{15,16}$ In mice, expression of Sry is both brief and carefully regulated; however, the factors controlling this burst of expression remain unknown. One of the factors postulated to play a role in activation of Sry is Wilms' tumour 1 (WT1), which can act as a 
transcriptional activator ${ }^{17,18}$ or repressor. ${ }^{19} \mathrm{WT} 1$ has two active isoforms in the gonad, with either an insertion or an omission of three amino acids, lysine $(\mathrm{K})$, tyrosine $(\mathrm{T})$ and serine $(\mathrm{S})$, between two zinc finger motifs. ${ }^{20,21}$ Each isoform has distinct functions during mouse testis determination. Knockout mice show that WT1+KTS, although unlikely to be directly regulating Sry expression, is required for maintenance of the gonad. ${ }^{20}$ However, this WT1 isoform has been shown to be able to transactivate the human $S R Y$ promoter in vitro. ${ }^{22}$ Conversely, WT1+KTS-null mice exhibit complete XY sex reversal, presumably due to abnormally low Sry expression. ${ }^{20}$ In agreement with the mouse model, WT1 haploinsufficiency, resulting in reduced levels of WT1+KTS, results in XY sex reversal in human patients. ${ }^{23}$ It is proposed that WT1+KTS is involved in cell-autonomous regulation of Sry in vivo, as indicated by reduced SRY levels in cells of WT1+KTS-null mouse gonads. ${ }^{24}$ It is important when interpreting these results to take into account the fact that knocking out one WT1 isoform leads to an increase in expression of the other, which may have an impact on the observed phenotype and interaction with SRY.

In addition to sufficiently early onset of expression of Sry, a threshold level of expression must be achieved for complete testis differentiation to occur. In mice, expression of Sry is initiated at 10.5 days post-coitum (d.p.c.), peaks at 11.5 d.p.c. and is extinguished by 12.5 d.p.c. ${ }^{25-27}$ Sry expression occurs in a wave-like pattern, beginning in the central region of the gonad and expanding out towards the poles. ${ }^{28-31}$ In humans, SRY has a broader spatiotemporal expression profile, occurring in multiple tissues such as the adrenal and heart, and being maintained for longer in the testis, apparently through to adulthood. ${ }^{32}$ Sry/SRY is also expressed in the brain of mice and humans. ${ }^{32-34}$ In mice, SRY is expressed in a subset of nigrostriatal doperminergic neurons in the brain and appears to affect the specific motor behaviours they control. ${ }^{35}$ However, although SRY is suspected of being involved in sexual dimorphism of the brain, a specific role for SRY outside sex determination has yet to be conclusively demonstrated.

Before turning to the cellular role of SRY, it is important to discuss briefly the course of events that occur as the testis differentiates. The gonads arise from a pair of bipotential primordia known as the genital ridges. In males, differentiation of the bipotential supporting cell lineage into Sertoli cells results in organisation of the developing testis into two main compartments: the testis cords, which comprise aggregates of germ cells surrounded by a layer of Sertoli cells in turn encased by peritubular myoid cells, and the testis interstitium which includes the steroidogenic Leydig cells and the testis vasculature. The development of secondary sexual characteristics in the embryo, such as external genitalia, is directed by the testes. Thus, the morphogenesis of the bipotential gonads into testes dictates the phenotypic sex of the male individual (Figure 1).

In mice, the first known cellular difference between the XX and XY gonad after expression of Sry is the male-specific proliferation of the epithelium at the coelomic surface of the genital ridges. ${ }^{36,37}$ This sexspecific proliferation is thought to amplify the population of cells capable of differentiating into Sertoli cells, the first testicular cell type to differentiate, ${ }^{38}$ and is required for the formation of testis cords. ${ }^{36,37,39}$ Thus far, the molecular mechanism that induces coelomic epithelial proliferation is unknown. We do know a direct molecular target of SRY: the gene encoding the transcription factor Sox9 (Sry box-containing gene 9). ${ }^{40}$ Because testes develop normally in transgenic XX mice overexpressing Sox9, it appears that male-specific proliferation of the coelomic epithelium and all other aspects of foetal testis development are under the control, directly or indirectly, of SOX9. ${ }^{41,42}$

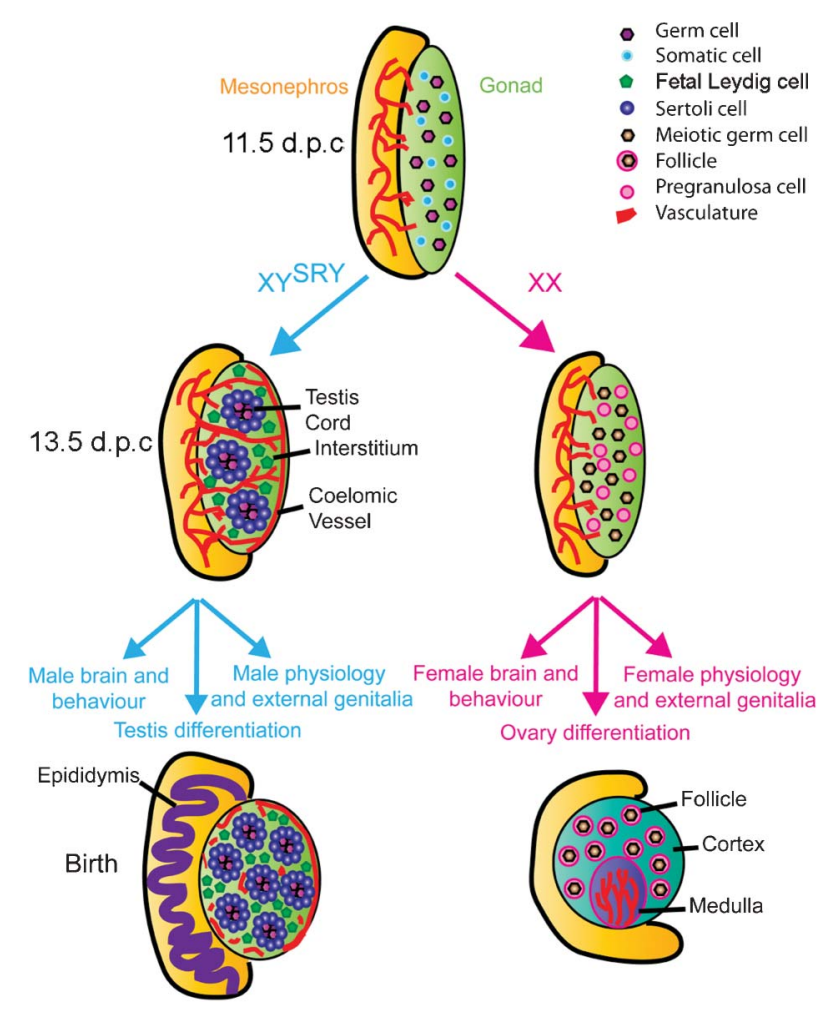

Figure 1 Overview of mouse gonadogenesis. The expression of Sry and Sox9 at 10.5-11.5 d.p.c. in the bipotential gonad initiates testis differentiation. By 13.5 d.p.c., basic testis morphology is established; the formation of testis cords, the coelomic blood vessel, and differentiation and activation of steroidogenesis in Leydig cells has occurred, and androgens are then produced by the testes. In the ovary, further differentiation is delayed. Around 13.5 d.p.c., germ cells have entered meiosis and vascularisation, and remodelling of the ovary to form germ cell cysts occurs. Later, the cortical and medullar domains begin to be established and folliculogenesis takes place. Secondary sexual characteristics include the establishment of the male and female genital tract and duct system, sexspecific brain dimorphisms and behaviours, and external genitalia. The establishment of secondary sexual characteristics involves organ-specific, regulatory gene networks. d.p.c., days post-coitum; FLC, foetal Leydig cell; Sox9, Sry boxcontaining gene 9; Sry/SRY, sex-determining region Y.

\section{SOX9 AND THE DIFFERENTIATION OF THE SERTOLI CELL}

Sox9 is upregulated when a protein complex of SRY and steroidogenic factor 1 ((SF1) nuclear receptor subfamily 5, group A, member 1) binds to a Sox9 enhancer element known as testis-specific enhancer of Sox9 core element (TESCO).$^{40}$ Like SRY, SOX9 is necessary for testis differentiation: mice lacking Sox9 undergo complete XY sex reversal, ${ }^{43,44}$ while $75 \%$ of human patients with a heterozygous mutation in SOX9 manifest with complete or partial XY sex reversal. ${ }^{45,46}$

The proposed mechanism for XY gonadal transcription of Sox9 during sex determination consists of three distinct phases, according to Sekido and Lovell-Badge. ${ }^{40}$ Firstly, SF1 initiates low-level transcription of Sox9 in XX and XY genital ridges. Secondly, SF1, in a complex with SRY, activates male-specific transcription of Sox9 in the male genital ridge via TESCO. High levels of SOX9 are then maintained in the XY gonad via an autoregulatory feedback loop. ${ }^{40,47}$ Indeed, in vitro studies using SF1, SRY and SOX9 mutant proteins, modelled on clinical human mutations from 46,XY DSD patients, support this model. These proteins failed to activate the human homologue of TESCO, providing a potential mechanism by which mutations resulting in partially functional proteins can present as DSDs. ${ }^{48}$ 
It is believed that bipotential supporting cells cell-autonomously differentiate into Sertoli cells under the influence of SRY and SOX9: this conclusion was drawn from XX-XY chimaera studies in which it was found that, when testes formed, almost all Sertoli cells were XY, while other cell types did not exhibit a chromosomal bias. ${ }^{49,50}$ However, some Sertoli cells were always found to be $\mathrm{XX},{ }^{49}$ indicating the existence of paracrine pathways by which SRY- and SOX9-positive cells can recruit additional cells (such as XX cells in the chimaera experiments, or cells that express unusually low levels of Sry in normal $\mathrm{XY}$ gonads) to the Sertoli fate.

Two independent mechanisms of Sertoli cell recruitment are known: fibroblast growth factor 9 (FGF9) and prostaglandin D2 (PGD2) recruitment. Kim et al. ${ }^{51}$ demonstrated using Fgf9-null mice, which exhibit XY sex reversal, ${ }^{52}$ that FGF9 is required only for the maintenance of SOX9 expression, not its initiation. However, ectopic application of FGF9 to XX gonads induces SOX9 expression. ${ }^{51,53}$ Hiramatsu et al. ${ }^{54}$ showed that $F g f 9$ expression occurs in a wave emanating from the central zone of the gonad similar to Sry and Sox9. Inhibition of FGF signalling repressed the expansion of the Sox9-positive domain in the XY gonad. Furthermore, removal of the central segment or isolation of the central domain of the testis before the expansion of $F g f 9$ signalling resulted in failure of tubulogenesis in the anterior and posterior segments. Based on these findings, Hiramatsu et al. ${ }^{54}$ proposed a system where FGF9 was produced in the central domain of the gonad by newly specified Sertoli cells, from which it was secreted and rapidly diffused towards the gonadal poles where it recruited cells to the Sertoli fate by reinforcing the expression of Sox9. This mechanism is supported by evidence from Fgfr2-null (FGF-receptor 2) mice whose phenotype is similar to Fgf9-null mice, displaying male-to-female sex reversal and suggesting FGFR2 is the receptor for FGF9 in the XY gonad. Indeed, conditional deletion of Fgfr2 in pre-Sertoli cells shows that FGFR2 is required in pre-Sertoli cell differentiation. ${ }^{55}$

Independently, PGD2, an early product of the testis, is also able to induce Sertoli cell differentiation in vivo by amplifying SOX9 activity and canalizing the male pathway. Treatment of XX gonads with PGD2 resulted in upregulation in Sox9 and its direct downstream target $A m h$ (the gene encoding anti-Müllerian hormone), masculinizing the XX gonad. ${ }^{56-58}$ However, Pgds (prostaglandin D2 synthase)-null testes, after a delay in Sertoli cell differentiation, develop normally, indicating that this mechanism is a nonessential backup system for Sertoli cell recruitment. ${ }^{56}$ The requirement of theses backup systems and the need to continually reinforce the male programme may stem from the weak but critical role of SRY and the need to actively suppress the underlying female programme. Existence of these recruitment mechanisms ensures that as many cells as required are pulled into the Sertoli fate to allow successful differentiation of the gonad.

\section{THE ROLE OF THE TESTIS VASCULATURE}

Vascular patterning in the gonad is a sex-specific process. ${ }^{59}$ Testis vasculature is formed by migration of endothelial cells into the developing testes. ${ }^{60,61}$ By 12.5 d.p.c., a prominent artery known as the coelomic blood vessel can be seen along the anterior-posterior length of the testis, in addition to extensive microvasculature. Ectopic coelomic vessel-like structures were observed in gonads of XX mice mutant for Rspo1 (R-spondin homologue 1), Wnt4 (wingless-related MMTV integration site 4), Fst (follistatin) and Ctnnb1 (catenin (cadherin-associated protein), beta 1). ${ }^{62-66}$ Rspo1 is a regulator of WNT4 signalling which involves Ctnnb1, while Fst is downstream of WNT4, ${ }^{67}$ implicating the WNT signalling pathway in vessel formation and patterning. Additionally, overexpression of Wnt4 disrupts normal testis vasculature, indicating that WNT4 inhibits formation of gonad vasculature. ${ }^{68}$ Notably, where testis vasculature is disrupted, as in the WNT4 overexpressing mice, Sertoli and foetal Leydig cells still differentiate. $^{65,68}$

Recently, it has been discovered that the vascularisation of the testis plays an important instructive role in testis cord formation. ${ }^{60,61}$ When endothelial migration was suppressed in testes by blocking vascular endothelial growth factors with VEGF-Trap or by using an antibody against vascular endothelial cadherin, testis cord morphogenesis was impaired. ${ }^{60,69}$ Antagonizing vessel maturation also reduced proliferation of interstitial mesenchymal cells that appear to segregate the precursor territories for testis cords; this proliferation could be rescued by the addition of platelet derived growth factor isoform $\mathrm{BB}$ (PDGF-BB) ${ }^{61,69,70}$ However, the mechanisms governing testis vascularisation and cord segregation are still unclear.

\section{LEYDIG CELLS: THE KEY TO PHENOTYPIC MASCULINISATION}

Foetal Leydig cells (FLCs) produce steroid hormones that reinforce male-specific differentiation of the testis (for review, see Ref. 71). The FLC populations in humans and mice are similar during foetal life, ${ }^{72,73}$ although observation of the induction of steroidogenesis largely limited to steroid level quantification. The origins of FLCs in humans remain unclear. In the mouse, FLCs arise by about 12.5 d.p.c. (for review, see Ref. 74), and recent work involving cell lineage tracing and live imaging suggests that they arise from multiple origins including the coelomic epithelium and the gonad/mesonephros border. ${ }^{53}$ Several pathways and molecules have been implicated in their differentiation and maintenance. SF1 marks presteroidogenic and preSertoli cells in the developing genital ridge $\mathrm{e}^{75,76}$ and acts as a key regulator of genes encoding steroid hydroxylases, which later distinguish FLCs. ${ }^{77}$ Members of the hedgehog signalling pathway, desert hedgehog $(\mathrm{DHH})$, which is secreted by Sertoli cells, and its receptor patched homologue 1 (PTCH1), which is expressed by the interstitium, have been shown to be positive regulators of FLC differentiation. ${ }^{78} \mathrm{Dhh}$ null mice have a FLC differentiation defect. ${ }^{78}$ Human patients with mutations in $\mathrm{DHH}$ present with mixed, partial or pure gonadal dysgenesis through to seemingly unaffected carriers. ${ }^{79-81}$ In addition, chemical inhibition of hedgehog signalling at 11.5 d.p.c. completely abolished expression of steroidogenic enzymes, confirming that DHH/PTCH1 signalling is essential for FLC differentiation. ${ }^{78}$ Gli1 (glioma-associated oncogene family zinc finger 1) and Gli2 (gliomaassociated oncogene family zinc finger 2) are downstream targets of hedgehog signalling and are expressed exclusively in the testis interstitium in a manner similar to PTCH1 ${ }^{82}$ However, Gli1- and Gli2-null mice display normal FLC differentiation, perhaps indicating functional redundancy between the GLI factors in FLCs. ${ }^{82}$ Ectopic activation of the hedgehog signalling pathway in SF1-positive ovarian cells is sufficient to differentiate these cells into functional FLCs within an ovarian environment. ${ }^{83}$ These ectopic cells upregulated SF1 and were able to partially masculinize the phenotype of the XX embryo. ${ }^{83}$ Additionally, Pdgfr- $\alpha$ (platelet-derived growth factor receptor, alpha polypeptide) and Arx (Aristaless-related homeobox) have been identified as being critical for FLC differentiation in knockout mouse models. $^{84,85}$

\section{GERM CELLS: THE ORIGIN OF SPERM}

Germ cells are the precursors of oocytes and spermatozoa in the foetal gonad. The sexual fate of the germ cell is determined by signalling factors that the germ cells are exposed to upon entry to the gonad, 
rather than by their chromosomal constitution. ${ }^{58,86-89}$ Much of what is known about the origin and regulation of the germ cells is derived from studies in mice, as discussed below.

In an ovary, germ cells must enter meiosis during foetal life if they are to initiate oogenesis correctly; conversely, meiosis must be avoided in male germ cells in the foetus if they are to embark on the spermatogenic pathway. The interplay between FGF9 and retinoic acid (RA) appears to be key to the correct specification of the germ cells in the mouse: meiosis is induced by RA in the foetal ovary and inhibited by FGF9, which is secreted by Sertoli cells, in the foetal testes. ${ }^{86-88,90}$ In the developing testis, meiosis is avoided because RA is degraded by the P450 enzyme CYP26B1 (cytochrome P450, family 26, subfamily b, polypeptide 1). ${ }^{91}$ Thus, CYP26B1 acts to suppress meiosis indirectly by the removal of RA, while FGF9 directly suppresses meiosis and acts to maintain pluripotency. ${ }^{86-88}$ This mechanism is supported by in vivo evidence from Cyp26B1-null mice where degradation of RA does not occur in XY gonads, resulting in upregulation of RA-responsive Stra8 (stimulated by retinoic acid gene 8 ) and germ cell entry into meiosis. ${ }^{87,91}$

Recently, a double-knockout of Aldh1a2/Aldha1a3 (aldehyde dehydrogenase family 1, subfamily A2/A3), genes encoding key synthesizers of RA in the mesonephros, demonstrated that some meiosis still occurred in the foetal ovary. ${ }^{92}$ These data indicate that either RA does not drive meiosis or, more likely, that there is an additional source of RA that remains in these mice. More in-depth analysis of this model will be required to clarify this point. Regardless, a strong antagonism exists between meiosis-promoting (female) factors and meiosis-suppressing (male) factors that push the resident germ cells into their respective fates.

Relatively, little is known about whether these mechanisms are used in humans. Culture experiments demonstrate that the RA initiates meiosis in the human ovary and can upregulate STRA8. ${ }^{93,94}$ However, it appears that the human gonad has the capacity to produce RA, evidenced by the strong expression of ALDHA1A1 (aldehyde dehydrogenase family 1 , subfamily A 1 ) in the ovary around the time of meiosis initiation. ${ }^{93,94}$ Most striking is the apparent lack of CYP26B1 expression in the foetal human testes and the expression of RA receptors, indicating that the testes may be exposed to, and may be able to respond to, RA, unlike the situation in the mouse. ${ }^{93,95}$

Male germ cells are fated to enter $G_{1} / G_{0}$ arrest in the foetal testes. ${ }^{89}$ Retinoblastoma 1 is a cell cycle regulator necessary for male germ cells to enter arrest at the appropriate time. In XY retinoblastoma 1-null mice, the germ cell population fails to enter $G_{1} / G_{0}$ arrest appropriately. ${ }^{96}$ To compensate cell cycle suppressors, cyclin-dependent kinase inhibitors $1 \mathrm{~b}$ and $2 \mathrm{~b}$ are upregulated and after a delay can induce arrest. $^{96}$

\section{OVOTESTES: WHAT THEY REVEAL ABOUT MALE-FEMALE ANTAGONISM IN THE EMBRYO}

The study of ovotestes in mouse models has provided numerous insights into the antagonism between the male and female pathways during sex determination. When the $\mathrm{Y}$ chromosome derived from Mus poschiavinus, $\mathrm{Y}^{\mathrm{POS}}$, is backcrossed to a C57/BL6 (B6) background, varying degrees of sex reversal are observed in the XY progeny. ${ }^{97}$ This phenomenon is thought to be due to defective interaction between Sry on $\mathrm{Y}^{\mathrm{POS}}$ and autosomal sex-determining genes in $\mathrm{B} 6 .{ }^{98}$ Detailed expression studies have shown that a delay in the commencement of Sry expression, and subsequently, Sox 9 expression is the likely cause of B6-Y ${ }^{\mathrm{POS}}$ partial sex reversal. ${ }^{98-100}$ Wilhelm et al. ${ }^{30}$ found that although Sry was expressed throughout the genital ridge in $\mathrm{B} 6-\mathrm{Y}^{\mathrm{POS}}$ mice, the upregulation of Sox9 and activation of downstream testis differentiation pathways only took place in the central zone where Sry expression was initiated. ${ }^{25,28,29,31}$ These findings indicate that expression of Sry in the poles, which in ovotestes differentiate into ovarian tissue, does not reach the required expression threshold early enough. This failure to upregulate Sox 9 in pre-Sertoli cells allows the expression of key ovarian differentiation genes and the engagement of the ovarian programme. Therefore, male-female antagonism underlies the successful differentiation of the gonad. When the balance of factors is altered, even slightly, the underlying battle between the testicular and ovarian fate is revealed.

\section{MOLECULAR BALANCING ACTS: EXAMPLES OF ANTAGONISM BETWEEN MALE AND FEMALE PATHWAYS}

In order to understand the molecular mechanisms behind male sex determination, we must also understand what is occurring molecularly in the antagonistic female programme at the time of sex determination. It has become clear that the ovarian programme, although it is considered the 'default', is an active genetic programme in its own right. ${ }^{101}$ The antagonism between the male and female pathways has been illustrated using genetic approaches (Figure 2). In an early study of male-female antagonism, the male pathway was suppressed by knocking out $F g f 9$; as a result, the female pathway was promoted, indicated by the upregulation of WNT4. ${ }^{51}$ Conversely, when the female pathway was suppressed by knocking out Wnt4, the male pathway was stimulated. ${ }^{102}$ This phenomenon correlates to cases in DSD patients where WNT4 loss or mutation results in XX masculinisation and duplication results in XY feminisation. ${ }^{68,103}$ This male-female antagonism is further supported by ex vivo work. Treatment of XX gonads with ectopic FGF9 suppressed normal WNT4 expression and induced ectopic upregulation of Sox $9 .^{51}$ Thus, readouts of the male
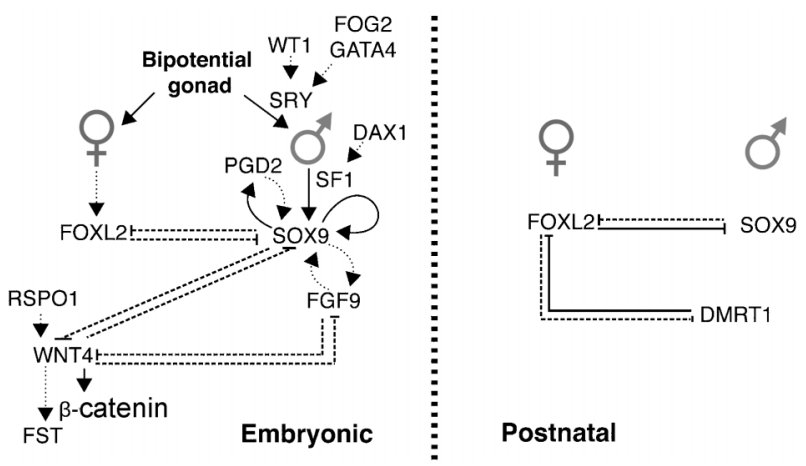

Figure 2 Model of molecular interactions and proposed levels of antagonism in testis and ovary. For details see text. In the embryonic XY gonad, Sry is activated via a mechanism involving WT1 (indirect regulation illustrated by dotted arrow/ line). SRY then directly upregulates Sox9, direct regulation illustrated by solid arrow/line) which maintains its own expression; positive feedback loops exists between PGD2/SOX9 and FGF9/SOX9. In the XX gonad, FOXL2 is active as are RSPO1, $\beta$-catenin and WNT4, which is required for expression of Fst. During embryonic development, antagonism is though to exist between FGF9/WNT4, SOX9/WNT4 and SOX9/FOXL2. Postnatally, antagonism exists between SOX9/ FOXL2 and DMRT1/FOXL2. DAX1, NrOb1, nuclear receptor subfamily 0, group B, member 1; DMRT1, doublesex and mab-3-related transcription factor 1; FGF9, fibroblast growth factor 9; FOG2, 'Friend of Gata1' type 2; FOXL2, forkhead box L2; Fst/FST, follistatin; GATA4, GATA-binding protein 4; PGD2, prostaglandin D2; RSP01, R-spondin homologue 1; SF1, steroidogenic factor 1; Sox9/SOX9, Sry box-containing gene 9; Sry/SRY, sex-determining region Y; WNT4, wingless-related MMTV integration site 4; WT1, Wilms' tumour 1. 
pathway, SOX9 and FGF9 can increase in response to a weakening of the female programme and vice versa.

Recent studies have shown that the balance between the antagonistic testicular and ovarian differentiation programmes is also important postnatally. Gonad-specific transcription factors doublesex and mab-3-related transcription factor 1 (DMRT1) and forkhead box L2 (FOXL2) have roles in maintenance of the testes and ovaries respectively. ${ }^{104}$ In humans, DMRT1 hemizygosity may result in hypogonadism, often with streak gonads. ${ }^{105}$ FOXL2/FoxL2 is a key ovarian marker, and its mutation is associated with premature ovarian failure in human patients and knockout mice. ${ }^{104,106,107}$ Dmrt1-null males were found to have numerous FOXL2-positive cells in the seminiferous tubules 4 months after birth. ${ }^{108}$ A Sertoli cell-specific knockout of Dmrt1 confirmed that loss of DMRT1 in Sertoli cells and not germ cells allows ectopic FOXL2 expression. ${ }^{108}$ However, FOXL2 may also be able to repress DMRT1, as shown by strong upregulation of DMRT1, when FOXL2 is ablated postnatally, ${ }^{109}$ suggesting the existence of a mutual antagonism necessary for maintaining sex differentiation throughout life.

FOXL2 has also been shown to antagonize SOX9 in the adult ovary and is postulated to also play a role in the embryonic testes. Conditional deletion of FoxL2 at 8 weeks resulted in transdifferentiation of granulosa cells in the adult ovary to Sertoli-like cells expressing SOX9 even in the presence of oocytes and theca cells, the steroidogenic cells of the ovary, differentiated into Leydig-like cells. ${ }^{109}$ In the adult ovary, it was demonstrated using chromatin immunoprecipitation that FOXL2 can repress TESCO activity, ${ }^{109}$ providing a possible mechanism for the role of FOXL2 in maintaining ovarian function postnatally. FoxL2 is also upregulated in $\mathrm{XY}$ embryonic gonads of Sox9-conditional null mice indicating that a similar mechanism exists during embryonic sex differentiation. ${ }^{43}$ However, importantly, expression of male and female factors in the gonad is exclusive, as observed in the ovotestes, ${ }^{30}$ such that FOXL2 and SOX9 are never coexpressed in the same cell. Nevertheless, while the factors mentioned in the above section are responsive to each other's loss, direct interaction and antagonism between any of these factors is yet to be demonstrated.

\section{SF1: HIGHLIGHTING THE ROLE OF GENE DOSAGE DIFFERENCES IN THE MOUSE AND HUMAN}

SF1 is a striking example of a factor whose effects on gonadal phenotype are sensitive to dosage and genetic background. ${ }^{75}$ Sf1-null mice undergo early gonadal and adrenal development, but the organs regress by 11.5 d.p.c. ${ }^{75,110}$ Transgenic expression of SF1 in Sf1-null mice was able to rescue gonad development, but not adrenal development. ${ }^{111}$ Additionally, Sf1-haploinsufficient mice have disrupted adrenal development but develop testes normally. ${ }^{112}$ Together, these results indicate that SF1 is involved in gonad and adrenal organ maintenance and that, in the mouse, the adrenal is more sensitive to Sf1 dosage than the gonad. However, there is evidence that the reverse is true in humans. Two patients with heterozygous mutations in SF1 have been shown to exhibit gonadal dysgenesis but normal adrenal function, indicating that, in humans, testis development is more sensitive to Sf1 dosage than adrenal gland development. ${ }^{113,114}$

\section{DAX1: A QUESTION OF GENE DOSAGE AND GENETIC BACKGROUND}

Daxl (NrOb1, nuclear receptor subfamily 0, group B, member 1) expression in the mouse indicates a role in early sex determination, with Dax1 being expressed in both sexes initially before being downregulated in the testes. ${ }^{31,115}$ Duplications of chromosomal region Xp21.2-21.1, which includes $D A X 1$, are sufficient to impair testis differentiation in 46,XY human patients and induce male-to-female sex reversal (dosage-sensitive sex reversal). ${ }^{116-118}$ These data imply that DAX1 acts as an antitestis gene, antagonizing the action of SRY. Similarly, overexpression of Dax1 in mice can induce male-to-female sex reversal. However, only mice highly overexpressing Daxl and which also have a weakened male sex-determining pathway driven by a $\mathrm{Y}^{\mathrm{POS}}$ chromosome, show complete male-to-female sex reversal. A common interpretation of these data is that mice and humans may have different sensitivity thresholds for DAX1 dosage.

An alternative explanation is that genetic background and the presence of genetic modifiers can explain whether or not gonad sex reversal occurs. Genetic background is a key determinant in the penetrance of a number of sex reversal phenotypes, with heterozygous mutants often displaying different phenotypes depending on their genetic background. Bouma et al. ${ }^{119}$ compared sex development in

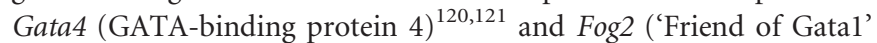
type 2; Zfpm2, zinc finger protein, multitype 2$)^{120,121}$ heterozygous mutants on $\mathrm{B} 6 / \mathrm{Y}^{\mathrm{AKR}}, \mathrm{B} 6, \mathrm{D} 2 / \mathrm{Y}^{\mathrm{AKR}}$ and $\mathrm{D} 2$ backgrounds, which have decreasing sensitivity to sex reversal. They found that ovaries or ovotestes developed in these mutants, but only on the $\mathrm{B} 6 / \mathrm{Y}^{\mathrm{AKR}}$ background. All other strains developed testes normally. These studies demonstrate the importance of genetic background, and also clearly indicate a role for GATA4 and FOG2 in foetal testis development. A similar background dependance was observed in the generation of sex-reversed Daxl mutant mice. ${ }^{31,122-124}$ Given that genetic background and the presence of genetic modifiers can explain whether or not gonad sex reversal occurs, it follows that effects attributed to differences in dosage sensitivity between humans and mice might also be explained by genetic background.

Given the expectation that Daxl acts as an antitestis gene, deletion of Dax1 in mice produced a surprising result: ovaries formed normally in Dax1-null XX mice, but in XY mice with a deletion of Daxl, testis cord formation was abnormal. ${ }^{123}$ Moreover, in $\mathrm{XY} \operatorname{Daxl}^{-1-} / \mathrm{Y}^{\mathrm{POS}}$ mice, complete male-to-female sex reversal was observed. ${ }^{124}$ Subsequent studies revealed the cause of the male-to-female sex reversal: Sox9 is not upregulated in XY Dax1-null mice, despite normal expression of Sry. ${ }^{125}$ Nonetheless, strong overexpression of Sry in $\mathrm{XY}^{\mathrm{POS}}$ Dax1-null mice was able to upregulate Sox9, correcting testis development and producing fertile males. ${ }^{125}$ These results are somewhat in accord with findings in humans, with respect to DAX1 mutations. 46 , XY patients with deletion of, or mutations in, DAX1, exhibit the male phenotype, but have hypogonadotrophic hypogonadism and disorganized testis cords, indicating that DAX1 is not essential for the initial stages of human gonad development, but is required for testis development. ${ }^{117,124,125}$ As there is evidence that DAX1 can work in both 'antitestis' and 'protestis' capacities, it is possible that correct function in the testis occurs only within a 'window' of activity involving two concentration thresholds. In this scenario, DAX1 activity beyond an upper threshold, for example, in cases of DAX1 duplication, may act to antagonize testis differentiation, while DAX1 activity below a lower threshold, for example, in cases of mutation, may allow ovarian differentiation to occur. ${ }^{126}$

\section{CONCLUSIONS AND PERSPECTIVES}

From the above discussion, it is clear that initial specification of Sertoli cells is a result of SRY expression, with the effects of SRY mediated largely if not entirely by SOX9. A complete understanding of male sex determination and testis morphogenesis, therefore, largely depends on a deeper understanding of the molecular and 
cellular roles of SOX9, and therefore, on the discovery and characterisation of all transcriptional targets of SOX9. Further, it remains to be clarified how the Sertoli cell directs events during morphogenesis; that is, what signalling molecules are produced by these cells and how they influence the differentiation of the other testicular cell lineages. How the other cell lineages, once masculinized, then contribute to testis morphogenesis is also a question that requires further investigation. A greater understanding of the molecular interactions involved in the process of testis differentiation will provide new avenues for DSD diagnosis and management.

Commitment to the male fate and then maintenance of that fate is achieved only by overcoming the progress of the female pathway, and antagonistic interplay is seen during foetal life, as well as postnatally. Mutual antagonism is likely to be facilitated by transcription factors such as SOX9 and FOXL2, but assays to determine the molecular interactions that underpin these antagonistic relationships have yet to be completed. Understanding what factors facilitate antagonism between the male and female programmes will lead to a greater understanding of what pushes individuals into or out of the two typical sex phenotypes specified by XX and XY chromosomes.

Additionally, as demonstrated here, sex-determining genes often respond in a dosage-dependent manner that may also be influenced by genetic background. As a result, human DSDs and mouse models may not always phenocopy each other, highlighting the need for a collaborative approach to DSD identification and diagnosis between researchers and clinicians. Human patient cases demonstrate, especially, that gene dosage and genetic background can be important factors in phenotype severity. However, despite this, the investigation of gene dosage effects and the effects of genetic background on sex determining genes in the mouse is a question that few researchers have addressed and that warrants further detailed investigation. Tools, such as inducible knockout and single-copy transgenesis strategies, are now available to study these phenomena in the mouse. Thus, better integration of lessons from both human cases and mouse models must be a priority. Finally, it is clear that integration of clinical findings and mouse models will contribute to a better understanding not only of the causes of human DSDs but also of the basic biology of sex determination in the male.

Abbreviations: DSD, disorder of sex development; DNA, deoxyribonucleic acid; HMG, high-mobility group-box; WT1/WT1/Wt1, Wilms Tumor 1; K, lysine; T, tyrosine; S, serine; Sry, sex determining region of Chr Y; SOX9/SOX9/Sox9, SRY-box containing gene 9; SF1/ SF1/Sf1 (Nr5a1), steroidogenic factor 1 (nuclear receptor subfamily 5 , group A, member 1); TESCO, testis-specific enhancer of Sox9 core element; FGF9/FGF9/Fgf9, fibroblast growth factor 9; PDG2/ $P D G 2 / P d g 2$, prostaglandin D2 synthase; FGF, fibroblast growth factor; FGFR2/FGFR2/Fgfr2, Fgf-receptor 2; AMH/AMH/Amh, antiMullerian hormone; PGDS/PGDS/Pgds, prostaglandin D2 synthase; dpc, days post coitum; WNT4/WNT4/Wnt4, wingless-related MMTV integration site 4; FLC, fetal Leydig cell; $\mathrm{DHH} / \mathrm{DHH} / \mathrm{Dh}$, desert hedgehog; PTCH1/PTCH1/Ptch1, patched homolog 1; GLI1/2/GLI1/ 2/Gli1/2, glioma-associated oncogene family zinc finger 1/2; PDGFR$\alpha /$ PDGFR- $\alpha /$ PDGFR $\alpha$, platelet derived growth factor receptor, alpha polypeptide; ARX/ARX/Arx, aristaless related homeobox; RA, retinoic acid; STRA8/STRA8/Stra8, stimulated by retinoic acid gene 8; RB1/ $R B 1 / R b 1$, retinoblastoma $1 ; C d k n 1 b / 2 b / C d k n 1 b / 2 b / C d k n 1 b / 2 b$, cyclin dependent kinase inhibitors 1b/2b; CYP26B1/CYP26B1/Cyp26b1, cytochrome P450, family 26, subfamily b, polypeptide 1; Aldh1a1/2/ 3/Aldh1a1/2/3/Aldh1a1/2/3, aldehyde dehydrogenase family 1 , subfamily A1/A2/A3; $\mathrm{Y}^{\mathrm{POS}}$, Y chromosome derived from Mus poschiavinus; $\beta$-catenin/CTTNB1/Ctnnb1, catenin (cadherin associated protein), beta 1; FOXL2/FOXL2/FoxL2, forkhead box L2; DMRT1/ DMRT1/Dmrt1, doublesex and mab-3 related transcription factor 1; FOG2/FOG2/Fog2, Zfpm2, zinc finger protein, multitype 2; GATA4/ GATA4/Gata4, GATA binding protein 4; DAX1/DAX1/Dax1, NrOb1, nuclear receptor subfamily 0 , group B, member 1 ; FST/FST/Fst, follistatin; RSPO1/RSPO1/Rspo1, R-spondin homolog; PDGF-BB, platelet derived growth factor isoform $\mathrm{BB}$.

\section{COMPETING FINANCIAL INTERESTS}

The authors declare no competing financial interests.

\section{ACKNOWLEDGMENTS}

We thank Elanor Wainwright for critical reading of this manuscript. This work was supported by research grants from the Australian Research Council (ARC) and National Health and Medical Research Council of Australia. PK is a Federation Fellow of the ARC.

1 Pasterski V, Prentice P, Hughes IA. Impact of the consensus statement and the new DSD classification system. Best Pract Res Clin Endocrinol Metab2010; 24: 187-95.

2 Gupta D, Bhardwaj M, Sharma S, Ammini A, Gupta D. Long-term psychosocial adjustments, satisfaction related to gender and the family equations in disorders of sexual differentiation with male sex assignment. Pediatr Surg Int 2010; 26: 955-8.

3 Blackless M, Charuvastra A, Derryck A, Fausto-Sterling A, Lauzanne K et al. How sexually dimorphic are we? Review and synthesis. Am J Hum Biol 2000; 12: 151-66.

4 Hughes IA, Houk C, Ahmed SF, Lee PA, LWPES1 Consensus Group et al. Consensus statement on management of intersex disorders. Arch Dis Child 2006; 91: 554-63.

5 Looijenga LH, Hersmus R, de Leeuw BH, Stoop H, Cools M et al. Gonadal tumours and DSD. Best Pract Res Clin Endocrinol Metab 2010; 24: 291-310.

6 Woodhouse CR. Prospects for fertility in patients born with genitourinary anomalies. J Urol 2001; 165: 2354-60.

7 Koopman P, Gubbay J, Vivian N, Goodfellow P, Lovell-Badge R. Male development of chromosomally female mice transgenic for Sry. Nature 1991; 351: 117-21.

8 Gubbay J, Collignon J, Koopman P, Capel B, Economou A et al. A gene mapping to the sex-determining region of the mouse $Y$ chromosome is a member of a novel family of embryonically expressed genes. Nature 1990; 346: 245-50.

9 Lovell-Badge R, Robertson E. XY female mice resulting from a heritable mutation in the primary testis-determining gene, Tdy. Development 1990; 109: 635-46.

10 Jager RJ, Anvret M, Hall K, Scherer G. A human XY female with a frame shift mutation in the candidate testis-determining gene SRY. Nature 1990; 348: 452-4.

11 Maier EM, Leitner C, Lohrs U, Kuhnle U. True hermaphroditism in an XY individual due to a familial point mutation of the SRY gene. J Pediatr Endocrinol Metab 2003; 16 575-80.

12 Nieto K, Pena R, Palma I, Dorantes LM, Erana L et al. 45,X/47, XXX/47, XX, del(Y)(p?)/ 46,XX mosaicism causing true hermaphroditism. Am J Med Genet A 2004; 130A 311-4.

13 Margarit E, Coll MD, Oliva R, Gomez D, Soler A et al. SRYgene transferred to the long arm of the $\mathrm{X}$ chromosome in a Y-positive XX true hermaphrodite. Am J Med Genet 2000; 90: 25-8.

14 Sharp A, Kusz K, Jaruzelska J, Tapper W, Szarras-Czapnik M et al. Variability of sexual phenotype in $46, X X(S R Y+)$ patients: the influence of spreading $X$ inactivation versus position effects. J Med Genet 2005; 42: 420-7.

15 Polanco JC, Koopman P. Sry and the hesitant beginnings of male development. Dev Biol 2007; 302: 13-24.

16 Kashimada K, Koopman P. Sry: the master switch in mammalian sex determination. Development 2010; 137: 3921-30.

17 Lee SB, Huang K, Palmer R, Truong VB, Herzlinger D et al. The Wilms tumor suppressor WT1 encodes a transcriptional activator of amphiregulin. Cell 1999; 98 663-73.

18 Shimamura R, Fraizer GC, Trapman J, Lau YfC, Saunders GF. The Wilms' tumor gene WT1 can regulate genes involved in sex determination and differentiation: SRY, Mullerian-inhibiting substance, and the androgen receptor. Clin Cancer Res 1997; 3: $2571-80$

19 Hewitt SM, Fraizer GC, Wu YJ, Rauscher FJ 3rd, Saunders GF. Differential function of Wilms' tumor gene WT1 splice isoforms in transcriptional regulation. J Biol Chem 1996; 271: 8588-92.

20 Hammes A, Guo JK, Lutsch G, Leheste JR, Landrock D et al. Two Splice variants of the Wilms' tumor 1 gene have distinct functions during sex determination and nephron formation. Cell 2001; 106: 319-29.

21 Haber DA, Sohn RL, Buckler AJ, Pelletier J, Call KM et al. Alternative splicing and genomic structure of the Wilms tumor gene WT1. Proc Natl Acad Sci USA 1991; 88: 9618-22.

22 Hossain A, Saunders GF. The human sex-determining gene $S R Y$ is a direct target of WT1. J Biol Chem 2001; 276: 16817-23.

23 Barbaux S, Niaudet P, Gubler MC, Grunfeld JP, Jaubert F et al. Donor splice-site mutations in WT1 are responsible for Frasier syndrome. Nat Genet 1997; 17: 467-70. 
24 Bradford ST, Wilhelm D, Bandiera R, Vidal V, Schedl A et al. A cell-autonomous role for WT1 in regulating Sry in vivo. Hum Mol Genet 2009; 18: 3429-38.

25 Hacker A, Capel B, Goodfellow P, Lovell-Badge R. Expression of Sry, the mouse sex determining gene. Development 1995; 121: 1603-14.

26 Jeske YW, Bowles J, Greenfield A, Koopman P. Expression of a linear Srytranscript in the mouse genital ridge. Nat Genet 1995; 10: 480-2.

27 Koopman P, Munsterberg A, Capel B, Vivian N, Lovell-Badge R. Expression of a candidate sex-determining gene during mouse testis differentiation. Nature 1990; 348: 450-2.

28 Albrecht KH, Eicher EM. Evidence that Sry is expressed in pre-Sertoli cells and Sertoli and granulosa cells have a common precursor. Dev Biol 2001; 240: 92-107.

29 Bullejos M, Koopman P. Spatially dynamic expression of Sry in mouse genital ridges. Dev Dyn 2001; 221: 201-5.

30 Wilhelm D, Washburn LL, Truong V, Fellous M, Eicher EM et al. Antagonism of the testis- and ovary-determining pathways during ovotestis development in mice. Mech Dev 2009; 126: 324-36.

31 Swain A, Narvaez V, Burgoyne P, Camerino G, Lovell-Badge R. Dax 1 antagonizes Sry action in mammalian sex determination. Nature 1998; 391: 761-7.

32 Clepet C, Schafer AJ, Sinclair AH, Palmer MS, Lovell-Badge R et al. The human SRY transcript. Hum Mol Genet 1993; 2: 2007-12.

33 Lahr G, Maxson SC, Mayer A, Just W, Pilgrim C et al. Transcription of the $Y$ chromosomal gene, Sry, in adult mouse brain. Brain Res Mol Brain Res 1995; 33: 179-82.

34 Mayer A, Lahr G, Swaab DF, Pilgrim C, Reisert I. The Y-chromosomal genes SRY and ZFY are transcribed in adult human brain. Neurogenetics 1998; 1: 281-8.

35 Dewing P, Chiang CW, Sinchak K, Sim H, Fernagut PO et al. Direct regulation of adult brain function by the male-specific factor SRY. Curr Biol 2006; 16: 415-20.

36 Schmahl J, Eicher EM, Washburn LL, Capel B. Sry induces cell proliferation in the mouse gonad. Development 2000; 127: 65-73.

37 Karl J, Capel B. Sertoli cells of the mouse testis originate from the coelomic epithelium. Dev Biol 1998; 203: 323-33.

38 Magre S, Jost A. The initial phases of testicular organogenesis in the rat. An electron microscopy study. Arch Anat Microsc Morphol Exp 1980; 69: 297-318.

39 Schmahl J, Capel B. Cell proliferation is necessary for the determination of male fate in the gonad. Dev Biol 2003; 258: 264-76.

40 Sekido R, Lovell-Badge R. Sex determination involves synergistic action of SRY and SF1 on a specific Sox9 enhancer. Nature 2008; 453: 930-4.

41 Vidal VP, Chaboissier MC, de Rooij DG, Schedl A. Sox9 induces testis development in XX transgenic mice. Nat Genet 2001; 28: 216-7.

42 Bishop CE, Whitworth DJ, Qin Y, Agoulnik Al, Agoulnik IU et al. A transgenic insertion upstream of Sox9 is associated with dominant XX sex reversal in the mouse. Nat Genet 2000; 26: 490-4.

43 Barrionuevo F, Bagheri-Fam S, Klattig J, Kist R, Taketo MM et al. Homozygous inactivation of Sox9 causes complete XY sex reversal in mice. Biol Reprod 2006; 74: 195-201.

44 Chaboissier MC, Kobayashi A, Vidal VI, Latzkendorf S, van de Kant HJ et al. Functional analysis of Sox8 and Sox9 during sex determination in the mouse. Development 2004; 131: 1891-901.

45 Foster JW, Dominguez-Steglich MA, Guioli S, Kwok C, Weller PA et al. Campomelic dysplasia and autosomal sex reversal caused by mutations in an $S R Y$-related gene. Nature 1994; 372: 525-30.

46 Wagner T, Wirth J, Meyer J, Zabel B, Held M et al. Autosomal sex reversal and campomelic dysplasia are caused by mutations in and around the $S R Y$-related gene SOX9. Cell 1994; 79: 1111-20.

47 Sekido R, Lovell-Badge R. Sex determination and SRY: down to a wink and a nudge? Trends Genet 2009; 25: 19-29.

48 Knower KC, Kelly S, Ludbrook LM, Bagheri-Fam S, Sim H et al. Failure of SOX9 regulation in 46XY disorders of sex development with SRY, SOX9 and SF1 mutations. PLOS ONE 2011; 6: e17751.

49 Palmer SJ, Burgoyne PS. In situ analysis of fetal, prepuberal and adult $X X-X Y$ chimaeric mouse testes: sertoli cells are predominantly, but not exclusively, XY. Development 1991; 112: 265-8.

50 Patek CE, Kerr JB, Gosden RG, Jones KW, Hardy K et al. Sex chimaerism, fertility and sex determination in the mouse. Development 1991; 113: 311-25.

51 Kim Y, Kobayashi A, Sekido R, DiNapoli L, Brennan J et al. Fgf9 and Wnt4 act as antagonistic signals to regulate mammalian sex determination. PLoS Biol 2006; 4: e187.

52 Colvin JS, Green RP, Schmahl J, Capel B, Ornitz DM. Male-to-female sex reversal in mice lacking fibroblast growth factor 9. Cell 2001; 104: 875-89.

53 DeFalco T, Takahashi S, Capel B. Two distinct origins for Leydig cell progenitors in the fetal testis. Dev Biol 2011; 352: 14-26.

54 Hiramatsu R, Harikae K, Tsunekawa N, Kurohmaru M, Matsuo I et al. FGF signaling directs a center-to-pole expansion of tubulogenesis in mouse testis differentiation. Development 2010; 137: 303-12.

55 Kim Y, Bingham N, Sekido R, Parker KL, Lovell-Badge R et al. Fibroblast growth factor receptor 2 regulates proliferation and Sertoli differentiation during male sex determination. Proc Natl Acad Sci USA 2007; 104: 16558-63.

56 Moniot B, Declosmenil F, Barrionuevo F, Scherer G, Aritake K et al. The PGD2 pathway, independently of FGF9, amplifies SOX9 activity in Sertoli cells during male sexual differentiation. Development 2009; 136: 1813-21.

57 Wilhelm D, Martinson F, Bradford S, Wilson MJ, Combes AN et al. Sertoli cel differentiation is induced both cell-autonomously and through prostaglandin signaling during mammalian sex determination. Dev Biol 2005; 287: 111-24.
58 Adams IR, McLaren A. Sexually dimorphic development of mouse primordial germ cells: switching from oogenesis to spermatogenesis. Development 2002; 129: 1155-64.

59 Brennan J, Karl J, Capel B. Divergent vascular mechanisms downstream of Sry establish the arterial system in the XY gonad. Dev Biol 2002; 244: 418-28.

60 Combes AN, Wilhelm D, Davidson T, Dejana E, Harley V et al. Endothelial cell migration directs testis cord formation. Dev Biol 2009; 326: 112-20.

61 Cool J, Carmona FD, Szucsik JC, Capel B. Peritubular myoid cells are not the migrating population required for testis cord formation in the XY gonad. Sex Dev 2008; 2: 128-33.

62 Tomizuka K, Horikoshi K, Kitada R, Sugawara Y, Iba Y et al. R-spondin 1 plays an essential role in ovarian development through positively regulating Wnt-4 signaling. Hum Mol Genet 2008; 17: 1278-91.

63 Chassot AA, Ranc F, Gregoire EP, Roepers-Gajadien HL, Taketo MM et al. Activation of beta-catenin signaling by Rspo1 controls differentiation of the mammalian ovary. Hum Mol Genet 2008; 17: 1264-77.

64 Liu CF, Bingham N, Parker K, Yao HH. Sex-specific roles of beta-catenin in mouse gonadal development. Hum Mol Genet 2009; 18: 405-17.

65 Jeays-Ward K, Hoyle C, Brennan J, Dandonneau M, Alldus G et al. Endothelial and steroidogenic cell migration are regulated by WNT4 in the developing mammalian gonad. Development 2003; 130: 3663-70.

66 Yao HH, Matzuk MM, Jorgez CJ, Menke DB, Page DC et al. Follistatin operates downstream of Wnt4 in mammalian ovary organogenesis. Dev Dyn 2004; 230: 210-5.

67 Tevosian SG, Manuylov NL. To beta or not to beta: canonical beta-catenin signaling pathway and ovarian development. Dev Dyn 2008; 237: 3672-80.

68 Jordan BK, Shen JH, Olaso R, Ingraham HA, Vilain E. Wnt4 overexpression disrupts normal testicular vasculature and inhibits testosterone synthesis by repressing steroidogenic factor 1/beta-catenin synergy. Proc Natl Acad Sci USA 2003; 100: 10866-71.

69 Cool J, DeFalco TJ, Capel B. Vascular-mesenchymal cross-talk through Vegf and Pdgf drives organ patterning. Proc Natl Acad Sci USA 2011; 108: 167-72.

70 Combes AN, Lesieur E, Harley VR, Sinclair AH, Little MH et al. Three-dimensional visualization of testis cord morphogenesis, a novel tubulogenic mechanism in development. Dev Dyn 2009; 238: 1033-41.

71 Wu X, Wan S, Lee MM. Key factors in the regulation of fetal and postnatal Leydig cell development. J Cell Physiol 2007; 213: 429-33.

72 Tapanainen J, Kellokumpu-Lehtinen P, Pelliniemi L, Huhtaniemi I. Age-related changes in endogenous steroids of human fetal testis during early and midpregnancy. J Clin Endocrinol Metab 1981; 52: 98-102.

73 Svechnikov K, Landreh L, Weisser J, Izzo G, Colón E et al. Origin, development and regulation of human leydig cells. Horm Res Paediatr 2010; 73: 93-101.

74 Griswold SL, Behringer RR. Fetal leydig cell origin and development. Sex Dev2009; 3: $1-15$.

75 Luo X, Ikeda Y, Parker KL. A cell-specific nuclear receptor is essential for adrenal and gonadal development and sexual differentiation. Cell 1994; 77: 481-90.

76 Hatano O, Takayama K, Imai T, Waterman MR, Takakusu A et al. Sex-dependent expression of a transcription factor, Ad4BP, regulating steroidogenic P-450 genes in the gonads during prenatal and postnatal rat development. Development 1994; 120: 2787-97.

77 Ikeda Y, Shen WH, Ingraham HA, Parker KL. Developmental expression of mouse steroidogenic factor-1, an essential regulator of the steroid hydroxylases. $\mathrm{Mol}$ Endocrinol 1994; 8: 654-62.

78 Yao HH, Whoriskey W, Capel B. Desert Hedgehog/Patched 1 signaling specifies fetal Leydig cell fate in testis organogenesis. Genes Dev 2002; 16: 1433-40.

79 Umehara $\mathrm{F}$, Tate $\mathrm{G}$, Itoh $\mathrm{K}$, Yamaguchi N, Douchi T et al. A novel mutation of desert hedgehog in a patient with 46,XY partial gonadal dysgenesis accompanied by minifascicular neuropathy. Am J Hum Genet 2000; 67: 1302-5.

80 Canto P, Soderlund D, Reyes E, Mendez JP. Mutations in the desert hedgehog $(D H H)$ gene in patients with $46, \mathrm{XY}$ complete pure gonadal dysgenesis. J Clin Endocrinol Metab 2004; 89: 4480-3.

81 Canto P, Vilchis F, Soderlund D, Reyes E, Mendez JP. A heterozygous mutation in the desert hedgehog gene in patients with mixed gonadal dysgenesis. Mol Hum Reprod 2005; 11: 833-6.

82 Barsoum I, Yao HH. Redundant and differential roles of transcription factors gli1 and gli2 in the development of mouse fetal Leydig cells. Biol Reprod 2011; 84: 894-9.

83 Barsoum IB, Bingham NC, Parker KL, Jorgensen JS, Yao HH. Activation of the Hedgehog pathway in the mouse fetal ovary leads to ectopic appearance of fetal Leydig cells and female pseudohermaphroditism. Dev Biol 2009; 329: 96-103.

84 Kitamura K, Yanazawa M, Sugiyama N, Miura H, lizuka-Kogo A et al. Mutation of ARX causes abnormal development of forebrain and testes in mice and X-linked lissencephaly with abnormal genitalia in humans. Nat Genet 2002; 32: 359-69.

85 Brennan J, Tilmann C, Capel B. Pdgfr-alpha mediates testis cord organization and fetal Leydig cell development in the XY gonad. Genes Dev 2003; 17: 800-10.

86 Bowles J, Feng CW, Spiller C, Davidson TL, Jackson A et al. FGF9 suppresses meiosis and promotes male germ cell fate in mice. Dev Cell 2010; 19: 440-9.

87 Bowles J, Knight D, Smith C, Wilhelm D, Richman J et al. Retinoid signaling determines germ cell fate in mice. Science 2006; 312: 596-600.

88 Koubova J, Menke DB, Zhou Q, Capel B, Griswold MD et al. Retinoic acid regulates sexspecific timing of meiotic initiation in mice. Proc Natl Acad Sci USA 2006; 103 : 2474-9.

89 McLaren A, Southee D. Entry of mouse embryonic germ cells into meiosis. Dev Biol 1997; 187: 107-13. 
90 Colvin JS, Feldman B, Nadeau JH, Goldfarb M, Ornitz DM. Genomic organization and embryonic expression of the mouse fibroblast growth factor 9 gene. Dev Dyn 1999 216: 72-88.

91 MacLean G, Li H, Metzger D, Chambon P, Petkovich M. Apoptotic extinction of germ cells in testes of Cyp26b1 knockout mice. Endocrinology 2007; 148: 4560-7.

92 Kumar S, Chatzi C, Brade T, Cunningham TJ, Zhao X et al. Sex-specific timing of meiotic initiation is regulated by Cyp26b1 independent of retinoic acid signalling. Nat Commun 2011; 2: 151

93 Childs AJ, Cowan G, Kinnell HL, Anderson RA, Saunders PT. Retinoic acid signalling and the control of meiotic entry in the human fetal gonad. PLOS ONE 2011; 6: e20249.

94 le Bouffant R, Guerquin MJ, Duquenne C, Frydman N, Coffigny H et al. Meiosis initiation in the human ovary requires intrinsic retinoic acid synthesis. Hum Reprod 2010; 25: 2579-90

95 Cupp AS, Dufour JM, Kim G, Skinner MK, Kim KH. Action of retinoids on embryonic and early postnatal testis development. Endocrinology 1999; 140: 2343-52.

96 Spiller CM, Wilhelm D, Koopman P. Retinoblastoma 1 protein modulates XY germ cell entry into $\mathrm{G}_{1} / \mathrm{G}_{0}$ arrest during fetal development in mice. Biol Reprod 2010; 82: 433-43.

97 Eicher EM, Washburn LL, Whitney JB, Morrow KE. Mus poschiavinus Y chromosome in the C57BL/6J murine genome causes sex reversal. Science 1982; 217: 535-7.

98 Albrecht KH, Young M, Washburn LL, Eicher EM. Sry expression level and protein isoform differences play a role in abnormal testis development in C57BL/6J mice carrying certain sry alleles. Genetics 2003; 164: 277-88.

99 Bullejos M, Koopman P. Delayed Sryand Sox9expression in developing mouse gonads underlies B6-YDOM sex reversal. Dev Biol 2005; 278: 473-81.

100 Nagamine CM, Morohashi KI, Carlisle C, Chang DK. Sex reversal caused by Mus musculus domesticus $Y$ chromosomes linked to variant expression of the testisdetermining gene Sry. Dev Biol 1999; 216: 182-94.

101 Nef S, Schaad O, Stallings NR, Cederroth CR, Pitetti JL et al. Gene expression during sex determination reveals a robust female genetic program at the onset of ovarian development. Dev Biol 2005; 287: 361-77.

102 Vainio S, Heikkila M, Kispert A, Chin N, McMahon AP. Female development in mammals is regulated by Wnt-4 signalling. Nature 1999; 397: 405-9.

103 Biason-Lauber A, Konrad D, Navratil F, Schoenle EJ. A WNT4 mutation associated with Müllerian-duct regression and virilization in a 46,XX woman. N Engl J Med2004; 351: 792-8.

104 Schmidt D, Ovitt CE, Anlag K, Fehsenfeld S, Gredsted L et al. The murine winged-helix transcription factor Foxl2 is required for granulosa cell differentiation and ovary maintenance. Development 2004; 131: 933-42.

105 Muroya K, Okuyama T, Goishi K, Ogiso Y, Fukuda S et al. Sex-determining gene(s) on distal 9p: clinical and molecular studies in six cases. J Clin Endocrinol Metab 2000; 85: 3094-100.

106 Crisponi L, Deiana M, Loi A, Chiappe F, Uda M et al. The putative forkhead transcription factor FOXL2 is mutated in blepharophimosis/ptosis/epicanthus inversus syndrome. Nat Genet 2001; 27: 159-66.

107 Uda M, Ottolenghi C, Crisponi L, Garcia JE, Deiana M et al. Fox/2 disruption causes mouse ovarian failure by pervasive blockage of follicle development. Hum Mol Genet 2004; 13: 1171-81.

108 Matson CK, Murphy MW, Sarver AL, Griswold MD, Bardwell VJ et al. DMRT1 prevents female reprogramming in the postnatal mammalian testis. Nature 2011 ; 476: $101-4$

109 Uhlenhaut NH, Jakob S, Anlag K, Eisenberger T, Sekido R et al. Somatic sex reprogramming of adult ovaries to testes by FOXL2 ablation. Cell 2009; 139: $1130-42$
110 Sadovsky Y, Crawford PA, Woodson KG, Polish JA, Clements MA et al. Mice deficient in the orphan receptor steroidogenic factor 1 lack adrenal glands and gonads but express P450 side-chain-cleavage enzyme in the placenta and have normal embryonic serum levels of corticosteroids. Proc Natl Acad Sci USA 1995; 92 10939-43.

111 Fatchiyah, Zubair M, Shima Y, Oka S, Ishihara S et al. Differential gene dosage effects of Ad4BP/SF-1 on target tissue development. Biochem Biophys Res Commun 2006, 341: 1036-45.

112 Bland ML, Fowkes RC, Ingraham HA. Differential requirement for steroidogenic factor-1 gene dosage in adrenal development versus endocrine function. $\mathrm{Mo}$ Endocrinol 2004; 18: 941-52.

113 Hasegawa T, Fukami M, Sato N, Katsumata N, Sasaki G et al. Testicular dysgenesis without adrenal insufficiency in a $46, \mathrm{XY}$ patient with a heterozygous inactive mutation of steroidogenic factor-1. J Clin Endocrinol Metab 2004; 89: 5930-5.

114 Mallet D, Bretones P, Michel-Calemard L, Dijoud F, David M et al. Gonadal dysgenesis without adrenal insufficiency in a $46, \mathrm{XY}$ patient heterozygous for the nonsense $\mathrm{C} 16 \mathrm{X}$ mutation: a case of SF1 haploinsufficiency. J Clin Endocrinol Metab 2004; 89: 4829-32.

115 Swain A, Zanaria E, Hacker A, Lovell-Badge R, Camerino G. Mouse Dax1 expression is consistent with a role in sex determination as well as in adrenal and hypothalamus function. Nat Genet 1996; 12: 404-9.

116 Bardoni B, Zanaria E, Guioli S, Floridia G, Worley KC et al. A dosage sensitive locus at chromosome Xp21 is involved in male to female sex reversal. Nat Genet 1994; 7 497-501.

117 Muscatelli F, Strom TM, Walker AP, Zanaria E, Recan D et al. Mutations in the DAX-1 gene give rise to both $X$-linked adrenal hypoplasia congenita and hypogonadotropic hypogonadism. Nature 1994; 372: 672-6.

118 Zanaria E, Muscatelli F, Bardoni B, Strom TM, Guioli S et al. An unusual member of the nuclear hormone receptor superfamily responsible for X-linked adrenal hypoplasia congenita. Nature 1994; 372: 635-41.

119 Bouma GJ, Washburn LL, Albrecht KH, Eicher EM. Correct dosage of Fog2 and Gata4 transcription factors is critical for fetal testis development in mice. Proc Natl Acad Sci USA 2007; 104: 14994-9.

120 Tevosian SG, Albrecht KH, Crispino JD, Fujiwara Y, Eicher EM et al. Gonada differentiation, sex determination and normal Sry expression in mice require direct interaction between transcription partners GATA4 and FOG2. Development 2002 129: 4627-34.

121 Tevosian SG, Deconinck AE, Cantor AB, Rieff HI, Fujiwara Y et al. FOG-2: A nove GATA-family cofactor related to multitype zinc-finger proteins Friend of GATA-1 and U-shaped. Proc Natl Acad Sci USA 1999; 96: 950-5.

122 Park SY, Lee EJ, Emge D, Jahn CL, Jameson JL. A phenotypic spectrum of sexual development in Dax1 (NrOb1)-deficient mice: consequence of the C57BL/6J strain on sex determination. Biol Reprod 2008; 79: 1038-45.

123 Meeks JJ, Crawford SE, Russell TA, Morohashi K, Weiss J et al. Dax1 regulates testis cord organization during gonadal differentiation. Development 2003; 130: 1029-36.

124 Meeks JJ, Weiss J, Jameson JL. Dax 1 is required for testis determination. Nat Genet 2003; 34: 32-3.

125 Bouma GJ, Albrecht KH, Washburn LL, Recknagel AK, Churchill GA et al. Gonadal sex reversal in mutant Dax1 $X Y$ mice: a failure to upregulate Sox 9 in pre-Sertoli cells. Development 2005; 132: 3045-54.

126 Ludbrook LM, Harley VR. Sex determination: a 'window' of DAX1 activity. Trends Endocrinol Metab 2004; 15: 116-21. 